\title{
KAJIAN PERBANDINGAN TENTANG KETETAPAN HUKUM ABORSI DI INDONESIA DAN CHILI
}

Rahmi Ayunda, Revlina Salsabila Roselvia; Fakultas Hukum, Universitas Internasional Batam, Indonesia; Jl. Gajah Mada, Baloi Permai, Kec. Sekupang, Kota Batam, Kepulauan Riau; E-mail: rahmi@uib.ac.id

\begin{abstract}
Abstrak
Abortus Provocatus atau yang biasa dikenal sebagai aborsi merupakan salah satu isu atau permasalahan yang sangat marak di dalam masyarakat. Indonesia dan Chili melarang perbuataan aborsi atau pengguguran kandungan karena hal ini melanggar Hak Asasi Manusia (HAM) sebab tidak memberikan kesempatan hidup kepada bayi atau janin di dalam kandungannya. Akan tetapi terdapat beberapa hal yang memperbolehkan adanya tindakan aborsi ini di dalam keadaankeadaan seperti adanya kedaruratan medis, korban pemerkosaan dan apabila janin terancam lahir tidak normal (dalam keadaan cacat) maka diperbolehkannya dilakukan tindakan aborsi tersebut. Jurnal ini akan memaparkan terkait penyebab dari tindakan aborsi dan juga dakwaan terkait orang yang melakukan aborsi maupun orang yang membantu proses aborsi atau menjual obat obatan yang digunakan untuk mempermudah aborsi ilegal. Metode penelitian yang digunakan adalah hukum normatif dengan pendekatan perundang-undangan (statute approach) dan perbandingan. Perbandingan yang akan dibahas yakni ketetapan hukum terkait aborsi di Negara Indonesia dan Negara Chili.
\end{abstract}

Kata Kunci: Aborsi, Hak Asasi Manusia (HAM), Ketetapan Hukum.

\section{Abstract}

Abortus Provocatus or commonly known as abortion is an issue were often found in the society these days. However, This matter is forbid in countries such as Indonesia and Chili because it violates the Human Right by taking the baby's chance to live. Moreover, abortion were allowed in few circumstances such as when facing medical emergency, being a rape victim or the baby diagnosed by some post birth disabilities. This journal will describe the cause of the abortion, as well as the accusation charged to people who did that, including them who help to carry on the process or selling the drugs to facilitate the action. The method used in this research is normative law with statute approach and comparison. Thus, the comparison that will be discussed is the legal provisions related to the abortion happened in Indonesia and Chili

Keywords: Abortion, Human Rights (HAM), Legal Lrovisions.

\section{PENDAHULUAN}

\section{Latar Belakang}

Aborsi merupakan hal yang marak dilakukan di Negara Indonesia karena disebabkan oleh beberapa faktor yaitu seperti anak yang tidak diinginkan atau kehamilan yang tidak diinginkan seperti kehidupan pergaulan remaja yang bebas dan Tindakan atau perilaku seks pranikah yang banyak ataupun marak dilakukan oleh remaja di perkembangan zaman modern sekarang ini dan hal ini disebabkan dengan adanya kehidupan pergaulan yang bebas dan pengaruh yang buruk dari lingkungannya misalnya seperti berteman dengan orang-orang yang memiliki pergaulan yang bebas dan tidak memiliki pengaruh baik ataupun emosi yang labil pada masa pendewasaan akan mendorong remaja melakukan hal-hal yang buruk ataupun terbawa pengaruh oleh orang disekitarnya. Dampak dari pergaulan yang bebas bagi remaja akan menyebabkan hal-hal yang menyimpang atau yang tidak seharusnya seperti tindakan kriminal, narkoba, kehidupan seks pranikah dan juga berkembangnya penyakit menular seperti HIV dan AIDS yang pada akhirnya akan merujuk kepada kematian dan mendongkrak tingginya 
angka kematian bagi Negara Indonesia sehingga diperlukannya wawasan akan hal seperti itu dan pengawasan dari orang tua agar mencegah terjadinya hal - hal menyimpang di dalam kehidupan remaja. ${ }^{1}$

Kehidupan seks pranikah juga merupakan salah satu dari banyaknya faktor penyebab aborsi dimulai dari pergaulan remaja yang ada di zaman sekarang sangatlah harus diperhatikan oleh para orang tua dikarenakan pergaulan yang bebas dapat membawa dampak negatif yang mana hubungan seks pranikah yang saat ini marak dilakukan oleh anak-anak remaja yang masih bersekolah yang mana hal ini dapat berdampak kepada hal-hal negatif seperti timbulnya penyakit dan juga dapat menjerumus ke perilaku aborsi yang mana jika hubungan ini dilakukan sebelum seseorang berumur 17 tahun maka akan sangat besar dampak atau resiko terdampak penyakit, yang mana semenjak tahun 2017 banyaknya terdapat kasus AIDS yang terus meningkat hingga bulan Juni tahun 2009 dan akibat dari hubungan seks pranikah yang menyebabkan seseorang terkena penyakit aids ini dapat berujung kepada kematian yang mana pada tahun 2014 Negara Indonesia banyak masyarakat yang terjangkit virus HIV/AIDS ini yaitu dengan angka sebesar 501.400 kasus selama tahun $2014 .{ }^{2}$

Aborsi merupakan salah satu isu kesehatan yang sangat berbahaya dan paling berdampak pada angka kematian di Negara Indonesia. Aborsi ini juga merupakan faktor ataupun dampak di dalam penyumbang besar terhadap kematian di Indonesia dimulai dari depresi, aborsi (pengguguran kandungan), penggunaan obat keras untuk menggugurkan kandungan dan juga kematian yang terjadi dikarenakan pendarahan yang terjadi saat dilakukannya tindakan aborsi tersebut. Aborsi ini aborsi telah dikenal sejak zaman dahulu dengan perantara menggunakan metode tradisional dan metode herbal seperti meminum jamu-jamuan ataupun teh herbal untuk menggugurkan janin tersebut dan aborsi ini juga dikenal dalam bahasa latin "abortus provocatus" yang memiliki arti bahwa seseorang dengan sengaja mengakhiri hidup kandungan atau janin yang ada di dalam rahim seorang wanita hamil baik disetujui ataupun tidak, aborsi provocatus ini juga merupakan istilah yang digunakan di dalam kalangan kedokteran dan hukum.

Aborsi merupakan suatu isu yang menimbulkan adanya pro dan juga kontra yang ada di dalam masyarakat dan aborsi ini bahkan telah menjadi pro kontra sejak zaman dahulu kala yang mana mengenai hal ini terdapat beberapa ahli yang setuju ataupun tidak setuju dengan adanya tindakan aborsi ini dan para ahli yang tidak setuju merupakan Phytagoras dan Hippocrates yang mengatakan tidak setuju mengenai tindakan aborsi ini yang mana menurut Phytagoras bahwa aborsi adalah penghilangan nyawa manusia kapanpun umur dari kandungan atau janin tersebut sedangkan Hippocrates metolak aborsi ini sendiri karena aborsi merupakan salah satu tindakan yang berbahaya dikarenakan dapat juga membahayakan nyawa dari sang ibu sehingga

${ }^{1}$ Dewi, A. K., \& Purwani, S. P. M. (2020). “Perlindungan Hukum Terhadap Anak Sebagai Korban Perkosaan yang Melakukan Aborsi". Kertha Wicara: Journal Ilmu Hukum, 9(4), 65-79., h. 67.

2 Kasim, F. (2014). "Dampak Perilaku Seks Berisiko terhadap Kesehatan Reproduksi dan Upaya Penanganannya (Studi tentang Perilaku Seks Berisiko pada Usia Muda di Aceh)". Jurnal Studi Pemuda, 3(1), h. 40. 
dengan adanya hal tersebut aborsi di larang di dalam dunia medis dan tidak ada satupun badan kesehatan yang diperbolehkan untuk melakukan tindakan aborsi tersebut. ${ }^{3}$

Aborsi ini sendiri memiliki dampak ataupun resiko seseorang setelah melakukan tindakan aborsi ini yang mana maraknya aborsi yang dilakukan oleh remaja yang masih dibawah umur yang disebabkan dari adanya hubungan seks pranikah dapat mempengaruhi resiko fisik, psikis dan juga dampak sosial yang mana resiko fisik yang dirasakan oleh seseorang yang telah melakukan tindakan aborsi yaitu mengalami pendarahan, adanya perubahan bentuk badan dan juga kurangnya imun tubuh sedangkan resiko psikis yang dialami yaitu adanya rasa trauma dan terdapat beberapa orang yang merasa bersalah karena telah melakukan tindakan aborsi dan yang paling berpengaruh yaitu munculnya rasa malu yang diakibatkan dari lingkungan sekitar jika orang - orang disekitarnya mengetahui akan tindakan aborsi yang dilakukannya maka akan merubah pandangan orang terhadap orang yang melakukan tindak pidana aborsi tersebut. ${ }^{4}$

Aborsi ini sendiri biasanya disebut dengan pengguguran kehamilan oleh wanitawanita yang tidak menginginkan anak di dalam kandungannya tersebut dan biasanya aborsi ini sendiri banyak dilakukan oleh wanita-wanita yang belum menikah atau dapat dikatakan sebagai kehamilan diluar nikah yang biasanya terjadi di kalangan anak-anak remaja yang masih memiliki emosi yang labil dan terkena dampak buruk dari pergaulan bebas yang sehingga terkenanya dampak dari perilaku seks pranikah dan aborsi ini merupakan salah satu hal yang dilarangdi dalam peraturan perundang-undangan, perlindungan anak, agama dan juga di dalam kesehatan. ${ }^{5}$ Hal ini sangat ditentang keras di dalam dunia kesehatan dan juga hukum dikarenakan aborsi melanggar Hak Asasi Manusia (HAM) dengan menghilangkan nyawa janin atau kandungan di dalam rahim seorang wanita yang membuat janin tersebut tidak memiliki kesempatan untuk hidup sehingga hal ini ditegaskan sebagai hal yang melanggar HAM dan ditentangnya aborsi di dalam dunia kesehatan dikarenakan hal ini sangat membahayakan bagi wanita yang melakukan tindakan aborsi ini sendiri karena dapat merenggut nyawa dari wanita tersebut maupun di dalam penggunaan alternatif lain seperti penggunaan dengan metode herbal ataupun meminum obat-obatan keras untuk menghilangkan nyawa dari janin atau kandungan tersebut sehingga hal ini sangat ditentang keras oleh negara. ${ }^{6}$

PKBI atau singkata dari Perkumpulan Keluarga Berencana Indonesia merupakan suatu Lembaga Swadaya Masyarakat (LSM) yang sudah berdiri sejak 23 Desember 1957

\footnotetext{
${ }^{3}$ Manohara, I. B. (2018, Desember). Penerapan Sanksi Pidana Bagi Pelaku Tindak Pidana Aborsi Menurut Peraturan Perundang-Undangan yang Berlaku (Kitab Hukum Pidana dan UndangUndang Nomor. 36 Tahun 2009 tentang Kesehatan). 3(1), h. 2.

${ }^{4}$ Hertanti, A. (2013, Juli). Aborsi (Studi Deskriptif Tentang Proses Pengambilan Keputusan Aborsi Ilegal yang Dilakukan oleh Remaja Putri di Kota Surabaya). (Doctoral dissertation, Universitas Airlangga)., h. $15-16$.

5 Shahrullah, R. S., Syarief, E., Sudirman, L., \& Surya, T. (2020). “Analisis Yuridis Pengaturan Abortus Provokatus Terhadap Korban Pemerkosaan di Indonesia". Jurnal Hukum Samudra Keadilan, 15(2), 251-263., h. 253.

6 Sibarani, S. (2016). "Tinjauan Penerapan Sanksi Pidana Terhadap Abortus Provocatus pada Korban Pemerkosaan". Jurnal Paradigma Hukum Pembangunan, 1(02), 119-130., h. 120.
} 
dan perkumpulan ini mempelopori atau menggerakkan hal-hal mengenai Keluarga Berencana (KB) di Indonesia. Salah satu alasan ataupun faktor yang membuat lahirnya lemabaga masyarakat ini dikarenakan tingginya angka kematian wanita di Indonesia baik dari yang berstatus menikah maupun belum menikah dan lembaga ini berfungsi sebagai sarana di masyarakat berfungsi sebagai sarana masyarakat di dalam mengurangi tingkat kematian wanita dikarenakan beberapa faktor dan salah satunya ialah kesehatan bagi ibu atau perempuan tersebut.

\section{Rumusan Masalah}

Berdasarkan latar belakang yang telah dikemukakan atau dipaparkan di atas maka permasalahan di dalam penelitian ini adalah sebagai berikut: 1) Bagaimana ketetapan hukum Negara Indonesia terkait orang-orang yang melakukan tindakan aborsi dan menjual obat aborsi di lingkungan masyarakat secara illegal?; dan 2) Bagaimana aborsi di Negara Chili serta ketetapan hukum terkait orang yang melakukan aborsi?.

\section{METODE PENELITIAN}

Penelitian ini menggunakan metode penelitian hukum normatif yang membahas mengenai permasalahan "aborsi ilegal" yang ada di Negara Chili dan Negara Indonesia yang menyebabkan meningkatnya angka kematian dikarenakan "aborsi ilegal" yang dilakukan oleh beberapa oknum-oknum tidak bertanggung jawab sehingga penelitian ini dibuat agar oknum-oknum tidak bertanggung jawab tersebut sadar akan hal - hal yang mereka lakukan secara ilegal. Penelitian Hukum Normatif merupakan penelitian yang dilakukan dengan cara meneliti data sekunder yang didapatkan oleh dan penelitian ini juga disebut sebagai penelitian hukum doktrinal yang mana proses ini dilakukan dengan cara menemukan aturan hukum maupun doktrin hukum mengenai tentang isu permasalahan hukum (aborsi) yang dihadapi oleh Negara Indonesia dan Negara Chili.

Pendekatan yang digunakan di dalam penelitian ini ialah pendekatan perundangundangan (statute approach) dan pendekatan perbandingan hukum, dikarenakan di dalam permasalahan ini harus dikaji lebih dalam mengenai tindak pidana dan perundang undangan apa sajakah yang dapat dilontarkan kepada oknum-oknum yang tidak bertanggung jawab tersebut baik dari pihak yang melakukan aborsi maupun individu ataupun sekumpulan orang yang menjual obat untuk tindakan aborsi illegal itu sendiri. Pendekatan perundang-undangan yang digunakan di dalam penulisan jurnal ini dikaji melalui Kitab Undang-Undang Hukum Pidana (KUHP) dan Ley Numero 21.030 (UndangUndang No 21.030 tentang Diskriminalisasi Gangguan Sukarela Kehamilan karena tiga penyebab) yang dilihat dari hal-hal apa sajakah yang dilanggar di dalam peraturan perundang-undangan tersebut.

Di dalam penelitian ini juga menelaah hal-hal yang terkait dengan permasalahan diatas maka sumber data dari penelitian ini ialah merupakan data sekunder yaitu data data hukum yang diperoleh dari studi kepustakaan yang mana hasil data yang dipaparkan didapatkan dari jurnal dan informasi berita. Dalam penelitian ini data yang digunakan yaitu terdiri dari 2 bahan yakin adalah bahan hukum sekunder, dan juga bahan hukum primer yang mana di dalam bahan hukum primer ialah suatu data 
maupun bahan hukum yang memiliki kekuatan mengikat seperti Peraturan Perundang Undangan sedangkan bahan hukum sekunder ialah bahan hukum yang menyajikan penjelasan-penjelasan mengenai bahan hukum primer seperti yang didapatkan dari beberapa tulisan seperti makalah, jurnal, dan artikel ilmiah yang terkait dengan "aborsi illegal" itu sendiri sedangkan bahan hukum tersier merupakan suatu bahan hukum yang memberikan penjelasan maupun pengertian mengenai hal - hal terhadap bahan hukum primer dan bahan hukum sekunder misalnya kamus hukum terkait dengan tema atau judul penelitian diatas dan sebagainya. Metode yang digunakan dalam menganalisis data-data yang didapat menggunakan metode deskriptif-kualitatif yang menganalisis data yang bersumber dari bahan hukum di dalam bentuk kalimat.

\section{PEMBAHASAN}

Ketetapan Hukum Negara Indonesia terkait Tindakan Aborsi dan Penjualan Obat Aborsi di Masyarakat secara Illegal

Aborsi berasal dari bahasa latin "abortus provocatus" yang mana merupakan pengguguran janin atau kandungan yang dilakukan secara sengaja oleh seorang ibu yang dapat dilihat dari beberapa faktor seperti harus dilakukannya suatu tindakan aborsi dikarenakan adanya kedaruratan medis ataupun korban dari tindakan pemerkosaan selebih dari 2 hal tersebut seseorang yang melakukan suatu tindakan aborsi dapat dijerat hukuman pidana dengan Pasal 346 Kitab Undang-Undang Hukum Pidana (KUHP) yang berbunyi, yaitu seseorang yang dengan sengaja menggugurkan, mematikan ataupun menyutuh orang lain untuk melakukan hal tersebut dapat dikenakan hukuman pidana kurang lebih selama 4 tahun dan hal mengenai aborsi ini harus ditekankan lagi oleh pemerintah Negara Indonesia dikarenakan maraknya praktek illegal terkait dengan tindakan aborsi dan juga penjualan obat - obatan secara illegal yang dijual di masyarakat dengan harga yang bervasiasi dan hal ini juga menyebabkan tingginya angka kematian yang ada di Negara Indonesia ini sendiri karena tidak amannya tindakan - tindakan terkait aborsi illegal yang hadir di tengan-tengah masyarakat Indonesia. ${ }^{7}$

Di dalam perkembangan zaman seperti sekarang ini sering sekali adanya pro dan kontra terkait mengenai isu "aborsi" yang secara illegal dilakukan oleh beberapa oknum yang kemudian juga menyebabkan tingginya angka kematian terhadap wanita maupun ibu di negara Indonesia dikarenakan oleh kurangnya keamanan dari tindakan aborsi ini sendiri karena hal ini masih illegal dilakukan oleh para wanita baik ibu di negara Indonesia ini sendiri jika janin tersebut tidak di dalam ketentuan - ketentuan terkait hal hal yang dapat memperbolehkan seseorang melakukan tindakan aborsi tersebut contohnya saja seperti jikalau bayi tersebut membahayakan Kesehatan ataupun nyawa dari ibu tersebut dan aborsi juga berlaku bagi korban tindakan pemerkosaan. Aborsi ini sendiri seperti yang kita ketahui merupakan hal yang telah ada sejak zaman dahulu yang mana tindakan aborsi dulu dilakukan dengan menggunakan ramuan-ramuan tradisional yang mana terbuat dari bunga ataupun teh yang bersifat herbal tetapi memiliki khasiat

7 Susanti, Y. (2012). "Perlindungan Hukum Bagi Pelaku Tindak Pidana Aborsi (Abortus Provocatus) Korban Pemerkosaan". Syiar Hukum, 14(2), h. 1-2. 
yang kuat yang mengandung kandungan-kandungan yang berbahaya untuk menggugurkan janin maupun kandungan yang ada di dalam kandungan seorang wanita.

Aborsi bukan merupakan hal yang baru di tengah-tengah masyarakat Indonesia maupun dunia dikarenakan tindakan dari aborsi illegal ini merupakan faktor yang menjadi penyumbang tingginya angka kematian, praktek dari aborsi ini sendiri banyak dilakukan ataupun dicari oleh kalangan remaja ataupun kalangan muda di lingkungan pelajar dikarenakan adanya pergaulan yang bebas yang membuat aborsi di negara Indonesia dapat mencapai angka 2,5 juta kasus aborsi pertahunnya dan sekitar 30\% dari jumlah tersebut merupakan penduduk yang berusia di kisaran 15-24 tahun dan hal ini dapat berujung dari beberapa faktor misalnya seperti Anak yang Tidak Diinginkan (ATD), permasalahan yang terkait dengan kesehatan baik dari pihak ibu maupun dari janin yang dikandungnya seperti yang kita lihat pada umumnya yang mana maraknya penjualan obat-obatan terlarang yang berfungsi atau memiliki khasiat untuk menggugurkan janin ataupun kandungan seseorang dan juga maraknya praktik aborsi illegal yang memakan biaya yang cukup besar. ${ }^{8}$

Tindakan praktik aborsi illegal banyak dilakukan dibeberapa kota besar di Indonesia salah satunya yaitu Ibukota Negara Indonesia yaitu DKI Jakarta, yang mana terbongkarnya praktik aborsi di daerah Jakarta Timur di dalam sebuah apartemen yang menawarkan jasanya sebesar Rp 10.000 .000 - Rp 15.000.000 yang dilihat dari kehamilan korban atau orang yang ingin melakukan tindakan aborsi tersebut dan di dalam pengakuannya tersangka mengaku telah mendapatkan 10 pasien dalam jangka waktu kurang lebih selama 3 bulan. ${ }^{9}$. Maraknya tindakan aborsi membuat pihak - pihak tertentu mencoba mengambil keuntungan secara illegal yang mana seperti membuka praktik dan juga menjual obat - obatan untuk membantu tindakan aborsi yang mana sama halnya dengan pasangan suami istri di daerah Sumatera Barat (Padang) yang menjual obat aborsi dengan harga Rp 300.000 sampai Rp 700.000 dan membantu aborsi dengan tarif Rp 5.000.000 sampai dengan Rp 7.000.00010 dan terdapat juga sebuah rumah sakit yang melakukan praktik aborsi secara illegal dari Januari 2019 sampai 10 April 2020 yang membantu 2.638 pasien aborsi secara illegal dan para pelaku terdiri dari beberapa tenaga medis yaitu dokter dan perawat dan para pelaku dikenakan beberapa pasal yaitu "Pasal 346, Pasal 299, Pasal 348 Ayat 1 atau Pasal 349 Kitab Undang - Undang Hukum Pidana

8 Nugroho, B. (n.d.). Perbuatan Aborsi dalam Aspek Hukum Pidana dan Kesehatanperbuatan Aborsi dalam Aspek Hukum Pidana dan Kesehatanperbuatan Aborsi dalam Aspek Hukum Pidana dan Kesehatan., h. 1.

9 Alpino, O. R. (2021). Rp10 Juta-Rp15 Juta, Tarif Aborsi di Apartemen Jakarta Timur. from sindonews.com: https://metro.sindonews.com/read/332266/170/rp10-juta-rp15-juta-tarif-aborsidi-apartemen-jakarta-timur-1613037727, diakses Maret 2021.

${ }^{10}$ Kompas.com. (2021). Pasutri Penjual Obat Aborsi di Padang Tetapkan Biaya Gugurkan Kandungan sampai Rp 7 Juta Artikel ini telah tayang di Kompas.com dengan judul "Pasutri Penjual Obat Aborsi di Padang Tetapkan Biaya Gugurkan Kandungan sampai $R p \quad 7$ Juta", from https://regional.kompas.com/read/2021/02/16/16261081/pasutri-penjual-obat-aborsi-dipadang-tetapkan-biaya-gugurkan-kandungan, diakses Maret 2021 
(KUHP) dan Pasal 194 juncto Pasal 75 Undang-Undang No 36 Tahun 2009 tentang Kesehatan". ${ }^{11}$

Aborsi sangatlah ditentang oleh peraturan perundang-undangan ataupun aturan hukum seperti Hukum Islam dan Kesehatan yang mana bahwa hal ini melanggar HAM karena menggugurkan janin ataupun kandungan yang ada di dalam rahimnya tersebut tanpa memberikan kesempatan dengan terkecuali terdapat beberapa faktor yaitu adanya kedaruratan medis seperti membahayakan nyawa sang ibu dan korban pemerkosaan di Negara Indonesia peraturan ataupun ketentuan hukum terkait dengan aborsi diatur di dalam Kitab Undang-Undang Hukum Pidana (KUHP) Bab XIX Pasal 346-350. Abortus provocatus atau yang biasa dikenal sebagai aborsi merupakan tindakan pengguguran janin atau kandungan secara sadar dan sengaja yang juga terbagi menjadi 2 bentuk yaitu aborsi provocatus medicinalis/aborsi artificialis therapicus yang mana masuk kedalam aspek kedaruratan medis yang ditangani oleh dokter demi menyelamatkan nyawa dari sang ibu jika masih mempertahankan janin ataupun kandungannya tersebut sehingga dengan segera diperlukannya tindakan aborsi. Syarat-syarat penuntuan indikasi medis antara lain dilakukan oleh tenaga medis, harus meminta pertimbangan dari psikologi dan ahli medis, harus adanya persetujuan tertulis dari pihak terkait atau keluarga terdekat, dilakukan di sarana kesehatan yang memiliki fasilitas yang lengkap yang dirujuk oleh pemerintah dan adanya prosedur dan laporan medis yang transparan. ${ }^{12}$

Aborsi provocatus criminalis yang merupakan salah satu isu yang sering diperdebatkan yaitu suatu tindakan pengguguran kandungan yang dilakukan secara illegal tanpa adanya indikasi medis atau kedaruratan medis hal ini dilakukan secara sadar dan sengaja dengan persetujuan dari sang ibu hal ini biasanya terjadi dikarenakan beberapa faktor yaitu, ATD, faktor ekonomi dan faktor lainnya yang mendukung agar dilakukannya tindakan aborsi illegal tersebut dan di dalam dunia medis waktu yang aman di dalam melakukan proses pengguguran kandungan (aborsi) yaitu saat pada kehamilan atau umur kandungan masih 6-10 minggu atau 2,5 bulan semenjak haid atau menstruasi terakhir sang ibu dan berdasarkan data yang kami kutip dari Sudramaji Sumapraja sebanyak $97 \%$ kalangan perempuan yang melakukan proses aborsi atau pengguguran janin atau kandungan yang ada di dalam rahimnya yaitu sebelum 12 minggu dari usia kandungannya. ${ }^{13}$

Kata aborsi merupakan salah satu tindakan pidana yang diatur di dalam perundangundangan Negara Indonesia salah satunya yaitu di dalam Kitab Undang-Undang Hukum Pidana (KUHP) Pasal 346, Pasal 347, Pasal 348 dan Pasal 349 dan di dalam UndangUndang No 36 Tahun 2009 tentang Kesehatan Pasal 75-77 mengenai hal-hal terkait dengan aborsi dan tindakan aborsi terhadap korban pemerkosaan juga diperbolehkan

${ }^{11}$ Raharjo, M. Y. W. (2020). Buka Praktik Aborsi Ilegal, Klinik dr. SWS Layani 2638 Pasien dalam Setahun. https://www.suara.com/news/2020/08/18/141631/buka-praktik-aborsi-ilegal-klinikdr-sws-layani-2638-pasien-dalam-setahun, diakses Maret 2021.

12 Susanti, Y. (2012). Perlindungan Hukum bagi Pelaku Tindak Pidana Aborsi (Abortus Provocatus) Korban Perkosaan. Syiar Hukum, 14(2), 297-298.

${ }_{13}$ Wijayati, M. (2015). Aborsi Akibat Kehamilan yang Tak Diinginkan (KTD): Kontestasi Antara Pro-Live dan Pro-Choice. Analisis: Jurnal Studi Keislaman, 15(1), h. 47 - 48. 
oleh Undang - Undang yang berlaku di Negara Indonesia yaitu di dalam Undang Undang No 36 Tahun 2009 tentang Kesehatan Pasal 75 Ayat 2 huruf b yang mengatur mengenai pengecualian terhadap korban pemerkosaan yang dilihat dari kekhawatiran di dalam segi mental atau trauma yang dialaminya akibat terjadinya pemerkosaan tersebut maka dengan itu "korban pemerkosaan" juga termasuk kedalam hal yang diperbolehkan untuk melakukan Tindakan aborsi dengan tujuan untuk melindungi atau mengurangi dampak dari trauma yang ia dapatkan dari tindak pidana pemerkosaan tersebut dan hal ini juga dapat menggunakan aturan lainnya yaitu Kitab Undang - Undang Hukum Pidana Pasal 48 terkait dengan daya paksa (overmacht) yang mana hal ini dilakukan dengan mengutamakan kepentingan dari korban atau untuk menyembuhkannya dari trauma atau bahkan hal ini juga dapat menggangu mental atau psikologi dari korban pemerkosaan tersebut ${ }^{14}$

Tindakan aborsi yang disengaja oleh seseorang juga dapat dijatuhkan dakwaan dengan menggunakan Pasal 194 Undang - Undang No 36 Tahun 2009 yang mana di dalam pasal ini berbunyi setiap orang yang dengan sengaja melakukan tindakan aborsi yang mana alasan dari tindakannya tersebut tidak masuk kepada kriteria - kriteria diperbolehkannya suatu Tindakan aborsi maka orang tersebut dapat dipidana dengan hukuman penjara 10 tahun paling lama atau denda sebanyak Rp 1.000.000.00015

Dalam peraturan perundang-undangan baik dari Undang-Undang Kesehatan maupun Kitab Undang-Undang Hukum Pidana (KUHP) segala tindakan terkait dengan aborsi yang dilakukan oleh seorang wanita tanpa masuk ke dalam kedaruratan medis dan juga merupakan korban pemerkosaan maka alasan apapun dianggap sebagai pelanggaran pidana yang juga melanggar Hak Asasi Manusia (HAM) di dalam konteks "menghilangkan nyawa janin yang ada di dalam kandungan atau rahim seorang wanita dan tidak memberikan kesempatan hidup bagi janin tersebut" maka dengan itu tindakan aborsi yang dilakukan oleh wanita tersebut termasuk ke dalam pelanggaran tindak pidana. Banyaknya kehamilan yang tidak diinginkan membuat maraknya praktik aborsi yang ada di Negara Indonesia dan penjualan obat-obatan keras yang mengandung bahan-bahan yang dapat menghilangkan nyawa dari janin yang ada di dalam kandungan seorang wanita dan kedua hal ini dilakukan atau dipasarkan secara illegal di dalam masyarakat dan hal ini kerap menimbulkan beberapa kontra yang mana dengan adanya praktik aborsi illegal ini sendiri berujung kepada kematian yang disebabkan tidak adanya penanganan medis seperti layaknya di sebuah rumah sakit, bahaya dari aborsi illegal ini sendiri juga menimbulkan gejala seperti munculnya pendarahan yang sangat banyak dan juga komplikasi pada sang ibu.

World Health Organization (WHO) memperkirakan ada sebanyak 20 juta kejadian aborsi tidak aman (unsafe abortion) atau dapat kita katakan sebagai aborsi illegal dan 9,5\%

14 Wulandari, R. (2019). “Pertanggungjawaban Pidana Terhadap Pelaku Abortus Provocatus Criminalis (Tindak Pidana Aborsi)". Jurnal Rechtens, 8(2), h. 206.

${ }^{15}$ Lestari, R. D. (2020). “Perlindungan Hukum Perempuan Pelaku Aborsi dari Korban Perkosaan Terhadap Ancaman Tindak Pidana Aborsi". MAGISTRA Law Review, 1(01), h. 16 - 17. 
(19 dari 20 juta tindakan aborsi tidak aman) diantaranya banyak terjadi di negara - negara berkembang yang salah satunya yaitu Negara Indonesia. ${ }^{16}$ Remaja di masa sekolah atau perkuliahan dalam rentang umur kurang lebih 15 - 24 banyak melakukan Tindakan aborsi yang mana dikarenakan hal ini dikarenakan kehidupan remaja yang masih labil di dalam pengambilan tindakan ataupun melakukan sesuatu hal yang menyebabkan timbulnya beberapa dampak negatif seperti adanya perilaku seksual pranikah yang membawa dampak buruk seperti adanya anak yang tidak diinginkan (ATD) yang membuat maraknya aborsi yang berakhir dengan kematian.

Di dalam dunia medis aborsi sangatlah ditentang walau dengan alasan apapun dikarenakan hal ini melanggar HAM dan merenggut nyawa dari seorang janin dan tidak memberikan kesempatan hidup dan Tindakan aborsi tersebut dilakukan tanpa termasuk kedalam pengecualian hal-hal yang telah ditetapkan ataupun diatur di dalam peraturan perundang-undangan yang berlaku di negara Indonesia yaitu adanya kedaruratan medis yang membahayakan janin ataupun nyawa sang ibu dan korban dari tindakan pemerkosaan yang dapat berdampak kepada gangguan mental ataupun trauma yang dihadapi oleh korban pemerkosaan tersebut dan hal ini diatur di dalam Undang-Undang No 36 Tahun 2009 tentang Kesehatan dalam Pasal 75 Ayat 2 huruf b dan Pasal 76 yang menjelaskan atau menguraikan hal-hal terkait dengan syarat-syarat pelaksanaan tindakan aborsi yang mana tindakan aborsi hanya dapat dilakukan jika termasuk dalam beberapa syarat atau ketentuan yang ditetapkan oleh undang-undang, yaitu: "Jika aborsi dilakukan sebelum umur kandungan atau kehamilan dari sang berumur 6 minggu dihitung dari pertama haid atau halangan terakhir dan hal ini dapat tetap dilaksanakan jika adanya hal mendesak seperti kedaruratan medis; tindakan aborsi dilakukan oleh tenaga kesehatan yang memiliki keterampilan, izin dan kewenangan yang juga memiliki sertifikat yang ditetapkan atau disetujui oleh menteri; dilakukan dengan adanya persetujuan dari pihak yang bersangkutan; dilaksanakan jika mendapatkan izin dari suami terkecuali terhadap korban tindak pemerkosaan; dan penyedia layanan kesehatan atau pelaksanaan tindakan aborsi telah memenuhi syarat yang ditetapkan oleh menteri dan izin terkait dengan pelaksanaan tindakan aborsi tersebut. ${ }^{17}$

Teknologi merupakan suatu hal yang sangat membantu masyarakat di dalam kegiatannya sehari-hari, kecanggihan teknologi di era 4.0 merupakan salah satu hal yang dapat berdampak baik dan juga buruk bagi masyarakat karena semua akses terkait halhal yang ada dapat di akses menggunakan teknologi yang semakin hari semakin canggih dan dengan adanya teknologi munculnya hal-hal positif dengan adanya e-commerce yang berupa penjualan ataupun pembelian barang secara online dan mudahnya mengakses sesuatu secara online dimulai dengan munculnya platform belanja online seperti Shopee, Tokopedia, Lazada, dan Bukalapak yang membuat seseorang dengan mudah menjual

16 Wardhani, D. A. (2017). Perilaku Aborsi pada Remaja di Kota Pontianak Provinsi Kalimantan Barat (Studi Kualitatif pada Mahasiswi di Universitas Muhammadiyah Pontianak), (Doctoral Dissertation)., h. 5.

${ }^{17}$ Sasmita, F. (2016). Kajian terhadap Tindakan Aborsi Berdasarkan Kehamilan Akibat Perkosaan., h. 7 . 
belikan suatu barang secara online dari tempat yang berbeda tetapi dibalik sisi positif yang ditimbulkan dari teknologi terdapat juga sisi negatif yang ditimbulkan dari teknologi ini sendiri yang mana dapat kita lihat maraknya penjualan obat-obatan di media online yang tidak dapat dikendalikan dan menjadi salah satu sarana bagi oknumoknum tertentu dalam memasarkan produk terlarang tersebut.

Penjualan obatan - obatan yang tidak memenuhi syarat ataupun ketentuan (illegal) adalah salah satu isu di dalam bidang Kesehatan terutama di dalam bidang farmasi yang mana beredarnya obat - obat secara bebas yang tidak memenuhi syarat banyak terjadi di dalam lingkungan masyarakat dan salah satunya banyak dari obat - obatan illegal tersebut berfungsi sebagai obat pembantu di dalam menggugurkan janin dan pemasaran dari obat - obatan illegal ini banyak ditemui di dalam platform jual beli online sehingga dapat dengan mudahnya dibeli oleh masyarakat sekitar yang mana contoh dari obat obatan illegal yang digunakan di dalam proses pengguguran kandungan yaitu seperti mibetec, prostokos, cytotec yang merupakan nama lain dari obat misoprostol yang mana seharusnya obat ini berfungsi sebagai penurun atau pereda dari naiknya asam lambung tetapi pada saat ini obat ini disalahgunakan menjadi obat penggugur kandungan sehingga membuat tindakan aborsi menjadi lebih mudah dikarenakan terdapat zat - zat ataupun kandungan di dalam obat ini yang merupakan kandungan yang dapat menggugurkan janin di dalam kandungan. Maraknya penjualan obat - obatan secara illegal baik melalui media online ataupun langsung dapat dikatakan melanggar peraturan yang ada dan dapat dikatakan sebagai tindak pidana yang melanggar suatu Undang - Undang No 36 Tahun 2009 tentang Kesehatan Pasal 196 yang menjelaskan terkait orang yang melakukan pemasaran, memproduksi dan juga menjual atau memasarkan obat - obatan yang illegal dengan sengaja dan mengetahui bahwa obat tersebut tidak sesuai dengan standart keamanan bagi masyarakat sehingga tidak diperjualbelikannya obat tersebut secara umum maka orang tersebut dapat dikenakan Pasal 196 dan Pasal 98 ayat 2 dan 3 maka pihak yang menjualbelikan obat - obatan secara illegal tersebut dapat dipidana dengan pidana penjara 10 tahun paling lama dan denda sebanyak Rp 1.000.000.000.18

\section{B. Aborsi dan Ketetapan Hukum terkait Orang yang Melakukan Tindakan Aborsi di Chili}

Negara Chili merupakan salah satu negara berkembang yang terletak di Benua Amerika, Chili merupakan salah satu negara yang melakukan hubungan kerjasama dengan Negara Indonesia dan sistem pemerintahan yang dianut oleh negara ini ialah pemerintahan presidensil yang mana kepala pemerintahan dan kepala negara merupakan presiden yang terpilih setiap 4 tahun sekali berbeda halnya dengan negara Indonesia presiden hanya boleh menjabat dalam 1 periode dan tidak dapat mencalonkan diri untuk periode yang akan datang. Chili merupakan salah satu dari sekian banyak kawasan di

18 Farid, M., \& Astuti, P. (2018). "Proses Penegakan Hukum Tindak Pidana Penjualan Obat Penggugur Kandungan Secara Ilegal (Studi Kasus di Kepolisian Resort Kota Sidoarjo)". Novum: Jurnal Hukum, 5(4), h. 2. 
wilayah amerika latin yang memiliki kondisi negara yang stabil di semua bidangnya. Hubungan kerjasama bilateral antara Indonesia dengan Chili sudah ada sejak lama dan di dalam perjanjian Kerjasama yang dilakukan oleh kedua negara ini bahwa dari kedua pihak negara menyetujui untuk tidak mencampuri urusan rumah tangga dari negara satu sama lain dalam bentuk menghormati negara tersebut. Indonesia dan Chili terus mengalami peningkatan di dalam hubungan kerjasama yang baik salah satunya yaitu kerjasama di dalam bidang ekonomi dan dalam menjunjung perjanjian kerjasama diantara kedua negara dibuatlah beasiswa terhadap diplomat muda Indonesia di Akademi Diplomatik Andres Bello dan ditawarkannya beasiswa terhadap pelajar di Negara Chili dalam program beasiswa darmasiswa yang berfungsi sebagai alat untuk mendalami Negara Indonesia dimulai dari bidang seni dan juga bahasa serta budaya Negara Indonesia selama satu tahun ${ }^{19}$

Walaupun Negara Chili memiliki produksi tambang yang ada di negaranya tidak merubah status negara berkembang yang ada pada negaranya dikarenakan Negara Chili memiliki ketidakseimbangan ekonomi yang sangat tinggi atau terdapatnya ketimpangan di dalam bidang ekonomi Negara tersebut dan Negara Chili ini juga memiliki melakukan kerjasama dengan Negara Indonesia di dalam Comprehensive Economic Partnership Agreement (CEPA) di dalam upaya meningkatkan peran di dunia internasional dan Negara Chili ini juga merupakan suatu negara yang menjungjung tinggi HAM.20

Chili adalah salah satu negara yang tidak mengizinkan tindakan aborsi dalam keadaan atau situasi apapun yang mana pada saat dilarangnya tindakan aborsi di Negara Chili ini terdapat organisasi LSM yang berjuang atas hak perempuan untuk melegalkan undang-undang terkait dengan aborsi yang tidak terlalu ketat dan hal ini dimulai dengan beberapa cara salah satunya yaitu melalui iklan berbayar yang dilakukan pada tahun 2003 di salah satu surat kabar nasional di Negara Chili yang mana terdapat 232 perempuan yang menyetujui atau menyatakan bahwa mereka telah melakukan tindakan aborsi dan menuntut agar Negara Chili melonggarkan hal-hal terkait dengan aborsi. Tindakan aborsi ini sendiri merupakan isu permasalahan di setiap negara dikarenakan tindakan aborsi yang kian hari makin marak dilakukan negara Chili memutuskan untuk menetapkan aborsi sebagai tindak pidana kejahatan pada tahun 1874 tetapi seiring berjalannya waktu dan berpindahnya kepemimpinan membuat aturan yang mana pada tahun 1931 ditetapkannya bahwa pihak yang membantu tindakan aborsi baik dari pihak dokter maupun sang ibu yang ingin melakukan tindakan aborsi tersebut tidak dikenakan hukuman pidana jika adanya kedaruratan medis atau menyangkut nyawa dari sang ibu. Pada tahun 1989 Presiden Chili yaitu Presiden Pinochet di akhir jabatannya menetapkan bahwa dilarangnya tindakan aborsi tersebut dan selama beberapa dekade baik perempuan-perempuan di negara chili maupun lembaga yang memperjuangkan hak -

${ }^{19}$ Kedutaan Besar Republik Indonesia di Santiago, Republik Chile. (2018). Profil Negara dan Kerja Sama. from https://kemlu.go.id/santiago/id/read/profil-negara-dan-kerjasama/54/information-sheet, diakses Maret 2021.

${ }_{20}$ Marsudi, R.L.P. (2016). Laporan Kinerja Tahun 2018. h. 2. 
hak wanita atas pelonggaran aborsi terus berjuang agar dirubahnya ketetapan terkait dengan tindakan aborsi. ${ }^{21}$

Pada kepemimpinan Presiden Michelle Bachelet disetujuinya undang-undang mengenai aborsi dalam keadaan-keadaan tertentu, yaitu jika membahayakan nyawa sang ibu dan jika janin tidak dapat hidup atau mengalami kecacatan dan korban pemerkosaan yang mana peraturan yang baru disepakati terkait dengan korban pemerkosaan dapat melakukan Tindakan aborsi jika dikandung oleh anak yang berada dibawah 14 tahun dan mengandung selama 14 hingga 18 minggu aturan mengenai korban pemerkosaan termasuk kedalam aturan yang baru disepakati karena pada awalnya negara Chili hanya menyepakati 2 ketentuan yaitu jika janin membahayakan nyawa sang ibu dan terdapat kecacatan ataupun janin tidak dapat berkembang lagi dan hakim menyetujui hal terkait dengan tindakan aborsi dikarenakan selama hamper 30 tahun banyaknya perempuanperempuan yang melakukan tindakan aborsi secara illegal. ${ }^{22}$

Aborsi di Chili diatur di dalam Undang-Undang No 21.030 yang mengatur tentang kehamilan yang disebabkan oleh beberapa faktor yaitu korban pemerkosaan, kedaruratan medis dan juga jika bayi di diagnosa terlahir cacat atau tidak dapat berkembang lagi dan Undang - Undang ini sudah berlaku semenjak September tahun 2017 yang mana hal ini merupakan salah satu kemajuan di negara Chili di dalam hak-hak perempuan semenjak diberlakukannya aturan ini terdapat sekitar 359 perempuan yang melakukan tindakan aborsi legal atau dilindungi oleh hukum tetapi masih adanya ketakutan akan penyalahgunaan yang dilakukan oleh beberapa oknum yaitu seperti berbohong menjadi korban pemerkosaan agar dapat melakukan tindakan aborsi dan tidak dikenakan hukum yang sudah sesuai dengan seharusnya yang mana ditetapkannya Undang-Undang No 21.030 menarik simpati masyarakat terhadap presiden Michelle Bachelet karena telah melonggarkan undang-undang terkait dengan tindakan aborsi. ${ }^{23}$

Aborsi di Negara Chili memiliki beberapa ketentuan di dalamnya yaitu terdapatnya 2 orang yang mendampingi remaja ataupun perempuan yang ingin melakukan tindakan aborsi yang di dalam hal ini memberikan dukungan maupun informasi terhadap tindakan aborsi tersebut di dalam proses menuju pengambilan keputusan yang akan dilakukan oleh perempuan tersebut, sesuai Undang - Undang yang berlaku kementrian Kesehatan di Negara Chili memberikan beberapa acuan atau dasar di dalam penentuan tindakan aborsi tersebut. Ketentuan aborsi yang dilegalkan oleh Presiden Chili Michelle Bachelet minumbulkan beberapa pro kontra yang mana hal ini terdapat di Lembaga Kesehatan swasta yang menganggap keberatan berdasarkan atas hati nurani dan juga hak untuk berserikat otonomi organisasi swasta yang mana rumah sakit swasta mendapatkan

${ }^{21}$ Human Rights Watch. (n.d.). Women's Human Rights: Abortion. from Women's Human Rights: https://www.hrw.org/legacy/women/abortion/chile.html, diakses Maret 2021.

22 Hazliansyah. (2015). Cile Legalkan Aborsi Akibat Perkosaan., from republika.co.id: https://www.republika.co.id/berita/nushg2280/cile-legalkan-aborsi-akibat-perkosaan, diakses Retrieved Maret 2021

23 Labbé Brites, T. F. (2018). Análisis de la indicación de interrupción voluntaria del embarazo introducida por la Ley No. 21.030 en el Artículo 119 No. 2 del Código Sanitario, denominada" aborto embriopático"., h. 1 - 2. 
biaya dari publik atau masyarakat sehingga tidak dapat menyediakan layanan aborsi tersebut dan hal ini sudah ditetapkan oleh undang-undang yang berlaku pada bulan januari tahun 2019.24

Tindakan aborsi di Negara Chili difasilitasi oleh negara di beberapa tempat sesuai dengn kriteria atau penyebab yang dialami oleh wanita tersebut yang mana kriteria atau penyebab tersebut dibagi menjadi 3 yaitu: Tidak membahayakan nyawa dari sang ibu; Janin mengidap penyakit bawaan atau yang didapatkan dari genetik; dan Usia kehamilan tidak lebih dari 12 minggu dan usia 14 tahun umur kehamilan tidak lebih dari 14 minggu. Klinik-klinik dalam penanganan aborsi tersebar menjadi beberapa tempat sesuai dengan kriteria atau penyebabnya, yaitu: Klinik Universitas Los Andes (semua penyebab); Klinik Indisa (penyebab III); Rumah Sakit Klinik Universitas Katolik Kepausan Chili (semua penyebab); dan Yayasan Rumah Sakit Paroki San Bernardo (semua penyebab). ${ }^{25}$

\section{PENUTUP}

Aborsi merupakan isu atau permasalahan yang dialami oleh dunia yang mana di setiap negara banyaknya perilaku aborsi secara illegal yang dilakukan. Aborsi ini ditentang di dalam seluruh peraturan perundang - undangan dan juga dari segi agama karena hal ini merupakan salah satu tindakan yang melanggar HAM karena menghilangkan nyawa janin yang dikandungnya tanpa memberikan kesempatan hidup dan kedua negara ini yaitu Indonesia dan Chili merupakan dua negara yang sangat menjunjung tinggi HAM dan melarang keras adanya penyebaran obat-obatan illegal sebagai alat pembantu aborsi dan aborsi tetapi terdapat pengecualian terhadap 3 hal yaitu adanya kedaruratan medis, terancamnya kehidupan dari janin yang ada di dalam kandungannya kelak dan korban pemerkosaan sehingga tindakan aborsi ini diperbolehkan jika termasuk kedalam 3 ketentuan yang telah ditetapkan oleh undangundang jika tindakan aborsi dilakukan tanpa termasuk kedalam ketiga ketentuan ini maka di Negara Indonesia orang tersebut dapat didakwa dengan Kitab Undang-Undang Hukum Pidana (KUHP) dan Undang-Undang No 36 Tahun 2009 tentang Kesehatan sedangkan di Negara Chili diatur di dalam Undang-Undang No 21.030 dan pengedaran obat-obatan illegal dalam membantu proses aborsi juga tidak dibenarkan dan dapat dikenakan hukuman pidana penjara. Obat yang diperjualbelikan secara illegal dalam membantu tindakan aborsi yaitu misoprostol yang mana obat ini digunakan oleh perempuan yang ingin menggugurkan kandungannya baik di Indonesia dan Chili dan obat ini mudah didapatkan baik di tempat-tempat seperti apotik yang menyeludupkan obat ini dan banyak diperjualbelikan secara online karena harga yang relatif murah dibandingkan dengan melakukan aborsi yang memakan biaya yang banyak maka orangorang dengan ekonomi tertentu menggunakan misoprostol sebagai alternatif di dalam pengguguran kandungannya. Di Chili tenaga kesehatan yang terbukti melakukan tindakan aborsi secara illegal akan dikenakan hukuman pidana penjara selama 3-5 tahun

${ }^{24}$ Maira, G., Casas, L., \& Vivaldi, L. (2019). Abortion in Chile: The long road to legalization and its slow implementation. Health and Human Rights, 21(2), h. 125 - 126.

25 Ministerio de Salud. (2019). Ley $N^{\circ} 21.030$ a 2 años de su entrada en vigencia. from www.minsal.cl: https://www.minsal.cl/ley-n21-030-a-2-anos-de-su-entrada-en-vigencia-ive/, diakses Maret 2021. 
sedangkan orang yang membantu proses aborsi selain tenaga kesehatan menerima hukuman pidana penjara kurang dari tiga tahun.

Aborsi merupakan masalah yang diusahakan diatasi oleh semua negara di dunia karena maraknya pergaulan bebas dan kurangnya pengawasan orang tua membuat dapat terjerumusnya seseorang ke dalam tindakan yang berhubungan dengan aborsi yang bahkan dapat berujung kepada kematian merupakan salah satu hal yang harus diperhatikan oleh para orang tua dan hal ini dapat dimulai dari mengawasi pergaulan remaja pada zaman sekarang dan pemerintah harus lebih mengawasi terkait penjualan online media elektronik (e-commerce) karena banyaknya penyeludupan terkait obatobatan illegal yang dapat dibeli secara online dengan praktisnya sehingga banyak menimbulkan kematian karena dosis yang digunakan tidak sesuai atau terjadinya overdosis yang menyebabkan kematian terhadap seseorang sehingga di dalam hal ini harus lebih diperhatikan lagi dari segala sisi yaitu baik dari sisi pemerintah didalam pencegahan peredaran obat-obatan illegal dan tindakan aborsi yang marak terjadi dan dari sisi orang tua yaitu mengawasi pergaulan dari remaja-remaja pada saat sekarang ini.

\section{DAFTAR PUSTAKA}

Alpino, O. R. (2021). Rp10 Juta-Rp15 Juta, Tarif Aborsi di Apartemen Jakarta Timur. from sindonews.com: https://metro.sindonews.com/read/332266/170/rp10-juta-rp15juta-tarif-aborsi-di-apartemen-jakarta-timur-1613037727, diakses Maret 2021.

Dewi, A. K., \& Purwani, S. P. M. (2020). Perlindungan Hukum Terhadap Anak Sebagai Korban Perkosaan yang Melakukan Aborsi. Kertha Wicara: Journal Ilmu Hukum, 9(4), 65-79.

Farid, M., \& Astuti, P. (2018). Proses Penegakan Hukum Tindak Pidana Penjualan Obat Penggugur Kandungan Secara Ilegal (Studi Kasus Di Kepolisian Resort Kota Sidoarjo). Novum: Jurnal Hukum, 5(4).

Hazliansyah. (2015). Cile Legalkan Aborsi Akibat Perkosaan., from republika.co.id: https://www.republika.co.id/berita/nushg2280/cile-legalkan-aborsi-akibatperkosaan, diakses Retrieved Maret 2021.

Hertanti, A. (2013, Juli). Aborsi (Studi Deskriptif Tentang Proses Pengambilan Keputusan Aborsi Ilegal yang Dilakukan oleh Remaja Putri di Kota Surabaya). (Doctoral dissertation, Universitas Airlangga).

Human Rights Watch. (n.d.). Women's Human Rights: Abortion. from Women's Human Rights: https://www.hrw.org/legacy/women/abortion/chile.html, diakses Maret 2021.

Kasim, F. (2014). Dampak Perilaku Seks Berisiko terhadap Kesehatan Reproduksi dan Upaya Penanganannya (Studi tentang Perilaku Seks Berisiko pada Usia Muda di Aceh). Jurnal Studi Pemuda, 3(1).

Kedutaan Besar Republik Indonesia Di Santiago, Republik Chile. (2018). Profil Negara dan Kerja Sama. from https://kemlu.go.id/santiago/id/read/profil-negara-dan-kerjasama/54/information-sheet, diakses Maret 2021.

Kompas.com. (2021). Pasutri Penjual Obat Aborsi di Padang Tetapkan Biaya Gugurkan Kandungan sampai Rp 7 Juta Artikel ini telah tayang di Kompas.com dengan judul "Pasutri 
Penjual Obat Aborsi di Padang Tetapkan Biaya Gugurkan Kandungan sampai Rp 7 Juta", from https://regional.kompas.com/read/2021/02/16/16261081/pasutri-penjualobat-aborsi-di-padang-tetapkan-biaya-gugurkan-kandungan, diakses Maret 2021.

Labbé Brites, T. F. (2018). Análisis de la indicación de interrupción voluntaria del embarazo introducida por la Ley No. 21.030 en el Artículo 119 No. 2 del Código Sanitario, denominada" aborto embriopático".

Lestari, R. D. (2020). “Perlindungan Hukum Perempuan Pelaku Aborsi Dari Korban Perkosaan Terhadap Ancaman Tindak Pidana Aborsi". MAGISTRA Law Review, 1(01).

Maira, G., Casas, L., \& Vivaldi, L. (2019). Abortion in Chile: The long road to legalization and its slow implementation. Health and Human Rights, 21(2).

Manohara, I. B. (2018, Desember). Penerapan Sanksi Pidana Bagi Pelaku Tindak Pidana Aborsi Menurut Peraturan Perundang-Undangan yang Berlaku (Kitab Hukum Pidana dan Undang-Undang Nomor 36 Tahun 2009 tentang Kesehatan). 3(1).

Marsudi, R.L.P. (2016). Laporan Kinerja Tahun 2018.

Ministerio de Salud. (2019). Ley $N^{\circ} 21.030$ a 2 años de su entrada en vigencia. from www.minsal.cl: $\quad$ https://www.minsal.cl/ley-n21-030-a-2-anos-de-su-entrada-envigencia-ive/, diakses Maret 2021.

Nugroho, B. (n.d.). Perbuatan Aborsi dalam Aspek Hukum Pidana dan Kesehatanperbuatan Aborsi dalam Aspek Hukum Pidana dan Kesehatanperbuatan Aborsi dalam Aspek Hukum Pidana dan Kesehatan.

Raharjo, M. Y. W. (2020). Buka Praktik Aborsi Ilegal, Klinik dr. SWS Layani 2638 Pasien Dalam Setahun. https://www.suara.com/news/2020/08/18/141631/buka-praktikaborsi-ilegal-klinik-dr-sws-layani-2638-pasien-dalam-setahun, diakses Maret 2021.

Sasmita, F. (2016). Kajian Terhadap Tindakan Aborsi Berdasarkan Kehamilan Akibat Perkosaan.

Shahrullah, R. S., Syarief, E., Sudirman, L., \& Surya, T. (2020). "Analisis Yuridis Pengaturan Abortus Provokatus Terhadap Korban Pemerkosaan di Indonesia". Jurnal Hukum Samudra Keadilan, 15(2), 251-263.

Sibarani, S. (2016). “Tinjauan Penerapan Sanksi Pidana Terhadap Abortus Provocatus pada Korban Pemerkosaan”. Jurnal Paradigma Hukum Pembangunan, 1(02), 119-130.

Susanti, Y. (2012). "Perlindungan Hukum Bagi Pelaku Tindak Pidana Aborsi (Abortus Provocatus) Korban Perkosaan". Syiar Hukum, 14(2), 297-298.

Susanti, Y. (2012). "Perlindungan Hukum Bagi Pelaku Tindak Pidana Aborsi (Abortus Provocatus) Korban Pemerkosaan". Syiar Hukum, 14(2).

Wardhani, D. A. (2017). Perilaku Aborsi Pada Remaja di Kota Pontianak Provinsi Kalimantan Barat (Studi Kualitatif Pada Mahasiswi di Universitas Muhammadiyah Pontianak), (Doctoral Dissertation).

Wijayati, M. (2015). “Aborsi Akibat Kehamilan yang Tak Diinginkan (KTD): Kontestasi Antara Pro-Live dan Pro-Choice". Analisis: Jurnal Studi Keislaman, 15(1).

Wulandari, R. (2019). Pertanggungjawaban Pidana Terhadap Pelaku Abortus Provocatus Criminalis (Tindak Pidana Aborsi). Jurnal Rechtens, 8(2). 